\title{
Dissipation of Phenanthrene and Anthracene from Soil with Increasing Salt Content Amended with Wastewater Sludge
}

\author{
Fabián Fernández-Luqueño ${ }^{1 *}$, Gaudencio Cabrera-Lázaro², \\ Langen Corlay-Chee ${ }^{2}$, Fernando López-Valdez ${ }^{3}$, Luc Dendooven ${ }^{4}$ \\ ${ }^{1}$ Sustainability of Natural Resources and Energy Program, Cinvestav-Saltillo, Coahuila, 25900 México \\ ${ }^{2}$ Universidad Autónoma Chapingo, Texcoco, 56230 México \\ ${ }^{3}$ CIBA - Instituto Politécnico Nacional, Tepetitla de Lardizábal, Tlaxcala, 90700 Mexico \\ ${ }^{4}$ Laboratory of Soil Ecology, GIB, Cinvestav, Mexico D.F, C.P., 07360 Mexico
}

Received: 17 July 2016

Accepted: 31 August 2016

\begin{abstract}
The removal of PAHs was stimulated by wastewater sludge in an alkaline saline soil of the former Lake Texcoco, but not always to the same extent. We investigated how a varying electrolytic conductivity (EC) affected the removal of phenanthrene (PHEN) and anthracene (ANTHR) from wastewater sludge-amended soils. Soil with EC 6, 30, 80, and $146 \mathrm{dS} \mathrm{m}^{-1}$ was contaminated with PHEN and ANTHR and amended with or without wastewater sludge, while emissions of $\mathrm{CO}_{2}$ and concentrations of ammonium, nitrite, and nitrate were monitored. A decrement on the concentrations of PHEN and ANTHR was observed and was faster in soil with EC $6 \mathrm{dS} \mathrm{m}^{-1}$ than in soil with EC $30 \mathrm{dS} \mathrm{m}^{-1}$ and $80 \mathrm{dS} \mathrm{m}^{-1}$, and was slower than in soil with EC $146 \mathrm{dS} \mathrm{m}^{-1}$. Adding wastewater sludge to soil reduced the concentration of PHEN and ANTHR in soil after 56 days. Spiking soil with PAHs or amending it with wastewater sludge increased the $\mathrm{CO}_{2}$ emission rate, but decreased at higher EC. The concentration of $\mathrm{NO}_{3}^{-}$decreased when soil was spiked with $\mathrm{PAHs}$ and amended with sludge, except in soil with EC $146 \mathrm{dS} \mathrm{m}^{-1}$. It was found that the removal of PAHs was not inhibited by salt content and a principal component analysis indicated that none of the measured soil characteristics, i.e., $\mathrm{pH}, \mathrm{EC}$, particle size distribution, water-holding capacity, or organic $\mathrm{C}$ content predicted the removal of ANTHR or PHEN from contaminated soil. The application of wastewater sludge increased the dissipation of PHEN and ANTHR after 56 days.
\end{abstract}

Keywords: mineral nitrogen, carbon dioxide emission, polycyclic aromatic hydrocarbons, soil degradation, soil organic matter

*e-mail: cinves.cp.cha.luqueno@gmail.com 


\section{Introduction}

High salt contents affect soil processes in many different ways. Excessive amounts of salts often result in poor soil structure and affect the chemical and biological processes while soil microbial biomass decreases due to its activity is inhibited. Carbon and nitrogen mineralization and soil enzyme activities, which are crucial for the decomposition of organic matter and their release of nutrients required to sustain soil productivity, are often inhibited by high salinity [1]. Consequently, salinity decreases the dissipation of polycyclic aromatic hydrocarbons (PAHs) in soils [2].

PAHs are widespread pollutants that can enter the environment as a result of the incomplete combustion of organic matter (e.g., residential heating, motor vehicles, gas, coal, and wood combustion) or from the spilling of mineral or tar oils [3]. PAHs are monitored because of their possible carcinogenic characteristics and their ubiquity in the environment. Although several hundred PAHs exist, most studies focus on the 16 PAHs listed by the U.S. Environmental Protection Agency and the European Community as pollutants [3]. Seven of them, including phenanthrene and anthracene, both are tricyclic aromatic hydrocarbons and their known effects as irritants of skin and eye, and that might be carcinogenic [4-5].

Sludge originating from wastewater treatment is frequently spread on land to restore degraded soils [6]. Wastewater sludge has a high organic matter content and is rich in nutrients, e.g., mainly nitrogen and phosphorous, stimulating plant growth. The application of wastewater sludge is known to accelerate the removal of PAHs from soil $[3,7]$. However, sludge can also contain contaminants such as heavy metals, pathogens, and organic pollutants, so that current regulations require a reduction in pathogen content and periodic monitoring for some metals prior to land application [7].

In a previous experiment that used soil from Texcoco ( $\mathrm{pH} 10.0$ and electrolytic conductivity (EC) $12 \mathrm{dS} \mathrm{m}^{-1}$ ), the application of wastewater sludge to soil accelerated the removal of phenanthrene (PHEN) and anthracene (ANTHR) and nearly halved their final concentrations after 112 days [8]. However, soils with $\mathrm{pH} 9.3$ and EC $7.3 \mathrm{dS} \mathrm{m}^{-1}$ for the application of wastewater sludge had no significant effect on the removal of ANTHR after 112 days [9]. It can be speculated that soil characteristics like salt content or the differences in wastewater sludge affected the remediation of PAHs from soil. Therefore, as part of a study for removal of PAHs from an alkaline saline soil using organic wastes, soil samples from the former Texcoco Lake at EC $6 \mathrm{dS} \mathrm{m}^{-1}, 30 \mathrm{dS} \mathrm{m}^{-1}, 80 \mathrm{dS} \mathrm{m}^{-1}$, or 146 $\mathrm{dS} \mathrm{m}{ }^{-1}$ were contaminated with PHEN and ANTHR and amended with the same wastewater sludge. The emissions of $\mathrm{CO}_{2}$, concentrations of mineral $\mathrm{N}$ [ammonium $\left(\mathrm{NH}_{4}^{+}\right)$, nitrite $\left(\mathrm{NO}_{2}^{-}\right)$, nitrate $\left(\mathrm{NO}_{3}^{-}\right)$], PHEN, and ANTHR were monitored in an aerobic incubation at $22 \pm 2^{\circ} \mathrm{C}$ for 56 days. The objective of this study was to investigate how salinity might affect the removal of PAHs when wastewater sludge was added to soil.

\section{Materials and Methods}

\section{Area description and Soil Sampling}

The soil samples were taken from soils of the former Texcoco Lake is Texcoco, Mexico, located at N $19^{\circ} 30^{\prime}, \mathrm{W} 98^{\circ} 53^{\prime}$ at an altitude of $2,250 \mathrm{~m}$ above sea level, with annual mean temperature of $16^{\circ} \mathrm{C}$ and annual mean precipitation of $600 \mathrm{~mm}$. The soil was characterized as alkaline-saline with $\mathrm{NaCl}$ and $\mathrm{Na}_{2} \mathrm{CO}_{3}$ as dominant minerals. The $\mathrm{pH}$ ranges were between 8.5 and 10.5, and electrolytic conductivity (EC) by saturation extracts were between 4 and $150 \mathrm{dS} \mathrm{m}^{-1}$ with a large exchangeable sodium percentage $(60-80 \%)$. Four different sites were selected with different ECs (Table 1). At each of the four sites, three $400 \mathrm{~m}^{2}$ plots were defined and the soil was sampled at random by augering the $0-15 \mathrm{~cm}$ top-layer 20 times. The soil from each plot was pooled separately so that 12 soil samples were obtained (four soils at different ECs by triplicate).

\section{PAHs and Sludge Characteristics}

The PHEN (purity $>98 \%$ ) and ANTHR (at $>97 \%$ ) were purchased from Sigma (USA), and acetone (at 99.7\%) was obtained from J.T. Baker (USA). Sewage sludge was acquired from Reciclagua Sistema Ecológico de Regeneración de Aguas Residuales Industriales in Lerma in the State of Mexico. Reciclagua is a water treatment plant that treats wastewater from different companies, while $90 \%$ of the wastewater is of food industry origin and $10 \%$ is from households. The sludge was sampled after the

Table 1. Some characteristics of the sampled soil in the former Lake Texcoco.

\begin{tabular}{|c|c|c|c|c|c|c|c|c|}
\hline & $\mathrm{EC}^{\mathrm{a}}$ & $\mathrm{pH}$ & Organic C & $\mathrm{WHC}^{\mathrm{b}}$ & Clay & Silt & Sand & Textural \\
\hline & $\left(\mathrm{dS} \mathrm{m} \mathrm{m}^{-1}\right)$ & & \multicolumn{5}{|c|}{ ( $\mathrm{g} \mathrm{kg}^{-1}$ soil $)$} & classification \\
\hline Texcoco A & 6 & 9.0 & 33 & 885 & 50 & 230 & 720 & Sandy loam \\
\hline Texcoco B & 30 & 10.6 & 41 & 656 & 90 & 60 & 850 & Loamy sand \\
\hline Texcoco C & 80 & 10.5 & 21 & 1098 & 180 & 310 & 510 & Sandy loam \\
\hline Texcoco D & 146 & 10.3 & 14 & 956 & 180 & 230 & 590 & Sandy loam \\
\hline
\end{tabular}

${ }^{\mathrm{a} E C}$ : Electrolytic conductivity, ${ }^{\mathrm{b}} \mathrm{WHC}$ : Water-holding capacity 
addition of a flocculent was passed through a belt filter to decrease water content. Forty kg of sludge were sampled aseptically in heavy-duty black plastic bags. Some sludge characteristics were $\mathrm{pH} 8.4$, water content $842 \mathrm{~g} \mathrm{~kg}^{-1}$, organic C content $509 \mathrm{~g} \mathrm{~kg}^{-1}$ dry sludge, and total N $55.3 \mathrm{~g} \mathrm{~kg}^{-1}$ dry sludge.

\section{Soil Preparation, Treatments and Experimental Set-up}

The soils from the four sites and each plot was sieved using a five mm sieve, and were adjusted to $40 \%$ of waterholding capacity (WHC) by adding distilled water $\left(\mathrm{H}_{2} \mathrm{O}\right)$. After that, the soils were kept at $22 \pm 2^{\circ} \mathrm{C}$ for 10 days in drums containing a beaker with $100 \mathrm{~mL} 1 \mathrm{M}$ sodium hydroxide $(\mathrm{NaOH})$ that was used to capture the $\mathrm{CO}_{2}$ produced, and a beaker with $100 \mathrm{~mL}$ distilled $\mathrm{H}_{2} \mathrm{O}$ to avoid desiccation of the soil.

Forty-eight sub-samples of $5 \mathrm{~g}$ soil of each of the 12 soil samples (three plots $\times$ four soils) were added to $120 \mathrm{~mL}$ glass flasks. Eighteen flasks were contaminated with $2 \mathrm{~mL}$ acetone in which PHEN and ANTHR were dissolved and amended with 1,162 mg fresh wastewater sludge $\mathrm{kg}^{-1}$ (Soil + PAHs + sludge), 18 were contaminated with $2 \mathrm{~mL}$ acetone where PHEN and ANTHR were dissolved (Soil + PAHs), and 18 were left unamended (Soil). The flasks were placed in a desiccator under vacuum for $20 \mathrm{~min}$, removed, and $15 \mathrm{~g}$ soil added to each flask. The soil was then mixed thoroughly. The amount of PAHs added to the $20 \mathrm{~g}$ soil was equivalent to 1,200 mg phenanthrene $\mathrm{kg}^{-1}$ and $520 \mathrm{mg}$ anthracene $\mathrm{kg}^{-1}$. To the wastewater sludge we added approximately $150 \mathrm{mg}$ inorganic $\mathrm{N} \mathrm{kg}^{-1}$.

Three flasks were chosen at random from each treatment of the three plots and four soils. Ten $\mathrm{g}$ soils were extracted for inorganic-N with $100 \mathrm{~mL} 0.5 \mathrm{M} \mathrm{K}_{2} \mathrm{SO}_{4}$ solution, and shaken for $30 \mathrm{~min}$ after being filtered through Whatman No. 42 filter paper and were analysed, while $1.5 \mathrm{~g}$ soil was extracted for PAHs with acetone and analysed on a gas chromatograph (GC). These provided zero-time samples.

The remaining flasks were arranged in $945 \mathrm{~mL}$ glass jars containing a vessel with $15 \mathrm{~mL}$ distilled $\mathrm{H}_{2} \mathrm{O}$ and a vessel with $20 \mathrm{~mL} 1 \mathrm{M} \mathrm{NaOH}$ to capture produced $\mathrm{CO}_{2}$. All jars were sealed and stored in a dark room at $22 \pm 2^{\circ} \mathrm{C}$ for 56 days. Additionally, 15 jars treated similarly to the other ones were sealed and served as controls to quantify the $\mathrm{CO}_{2}$ captured from the air. Three jars were selected at random from each treatment after 3, 7, 14, 28, and 56 days, while the soil was analysed for ammonium, nitrite, nitrate, and PAHs as mentioned before. All remaining flasks were opened and aired each of three days for $10 \mathrm{~min}$ to avoid anaerobic conditions. After that, they were sealed and incubated again.

\section{Chemical Analysis}

$\mathrm{pH}, \mathrm{EC}, \mathrm{WHC}$, particle size distribution, organic and inorganic $\mathrm{C}$ content, and total $\mathrm{N}$ and $\mathrm{NH}_{4}^{+}, \mathrm{NO}_{2}^{-}$, and
$\mathrm{NO}_{3}{ }^{-}$were measured in the soil according to FernándezLuqueño et al. [10].

\section{PAH Analysis}

Concentrations of PHEN and ANTHR in the substrate, i.e., soil, sludge, or both soil and sludge were extracted according to Song et al. [11]. The $1.5 \mathrm{~g}$ sub-sample of soil was mixed with $3 \mathrm{~g}$ of anhydrous sodium sulphate to form a fine powder and placed in a Pyrex tube; $5 \mathrm{~mL}$ acetone was added. The tubes were placed in a sonicated bath at $35-40^{\circ} \mathrm{C}$ for $20 \mathrm{~min}$, mechanically shaken on a vortex for $15 \mathrm{~s}$, and sonicated again for $20 \mathrm{~min}$. The extracts were separated from the soil by centrifuge at $3,000 \times$ rpm for $15 \mathrm{~min}$. This process was repeated three times. The extracts were combined, evaporated in a fume-cupboard at $50^{\circ} \mathrm{C}$, and dissolved in $2 \mathrm{~mL}$ acetone. From each tube, a $2.0 \mu \mathrm{L}$ aliquot was immediately analysed for PAHs on a HewlettPackard 4890-D GC (USA) fitted with a flame ionization detector. Additional technical specifications regarding $\mathrm{PAH}$ analysis and the percentage recovery of PAHs are described in Fernández-Luqueño et al. [10].

\section{Statistical Analyses}

Cumulative production of $\mathrm{CO}_{2}$ and concentrations of ammonium, nitrite, nitrate, PHEN, and ANTHR were subjected to one-way analysis of variance using PROC GLM [12]. Significant differences between treatments for $\mathrm{CO}_{2}$ emissions were determined using PROC MIXED [12]. Data shown are the mean of nine values $(n=9)$, i.e., three measurements of three plots.

The relationships between the different soil properties ( $\mathrm{pH}, \mathrm{WHC}$, organic $\mathrm{C}$, inorganic $\mathrm{C}$, clay, silt, sand, the emission of $\mathrm{CO}_{2}$, and concentration of $\mathrm{NO}_{3}{ }^{-}$after 56 days) were analyzed by principal component analysis (PCA) using the orthogonal/varimax rotation to achieve either small or large component loading and an eigenvalue of 1 as the lower limit. The matrix of 24 columns (sites) and 9 lines (variables) was used for principal component analysis. All analyses were performed using SAS statistical software [12].

\section{Results}

The emissions of $\mathrm{CO}_{2}$ resembled zero-order kinetics in all treatments of all soils (no data shown). In the unamended and uncontaminated soil (Soil), the $\mathrm{CO}_{2}$ emission rate was largest in soil with EC $6 \mathrm{dS} \mathrm{m}^{-1}$ and lowest in soil with EC $30 \mathrm{dS} \mathrm{m}^{-1}$ (Table 2). The $\mathrm{CO}_{2}$ emission rate was significantly higher in soil contaminated with PAHs compared to the unamended soil, but significantly lower than in the contaminated soil amended with wastewater sludge except for soil with EC $146 \mathrm{dS} \mathrm{m}^{-1}(p<0.05)$.

The concentrations of $\mathrm{NH}_{4}^{+}$decreased in the control treatment with EC 30 and $80 \mathrm{dS} \mathrm{m}^{-1}$ between days 14 and 28, and increased thereafter (Fig. 1a). In soil with EC 6 and $146 \mathrm{dS} \mathrm{m}^{-1}$ the concentrations of $\mathrm{NH}_{4}^{+}$showed an 


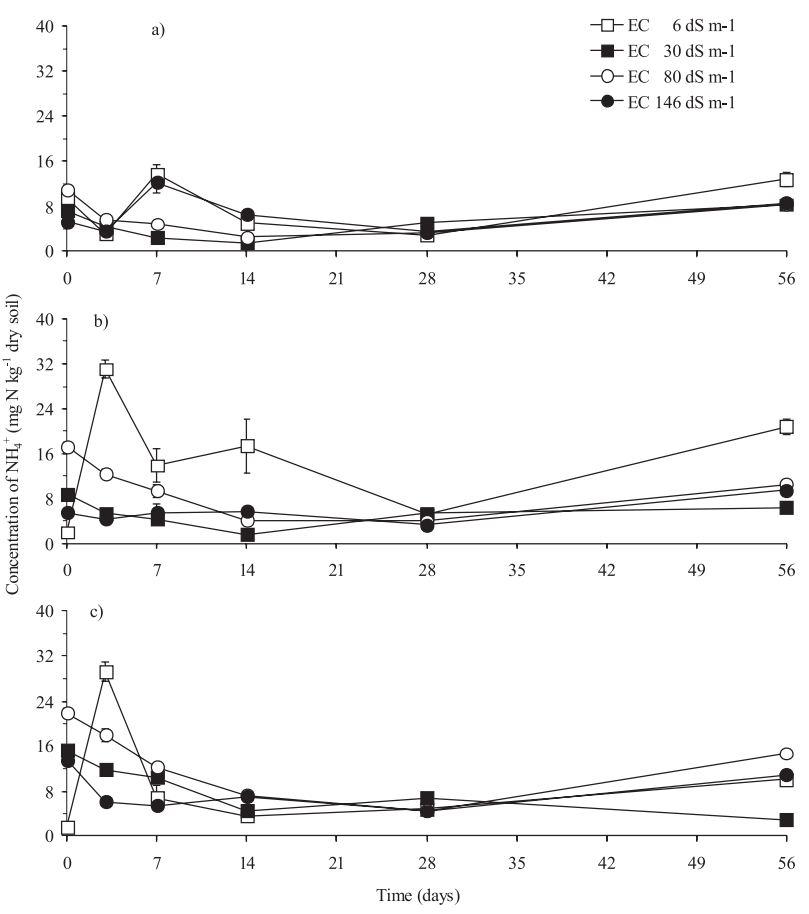

Fig. 1. Concentration of ammonium ( $\mathrm{mg} \mathrm{N} \mathrm{kg}^{-1}$ ) in a) soil, b) soil spiked with anthracene and phenanthrene, or c) soil spiked with anthracene and phenanthrene and amended with wastewater sludge with electrolytic conductivity (EC) $6 \mathrm{dS} \mathrm{m}^{-1}(\square), 30 \mathrm{dS}$ $\mathrm{m}^{-1}(\mathbf{\square}), 80 \mathrm{dS} \mathrm{m}^{-1}(\mathrm{O})$, or $146 \mathrm{dS} \mathrm{m}^{-1}(\bullet)$ incubated aerobically at $22 \pm 2^{\circ} \mathrm{C}$ for 56 days. Bars are \pm one standard deviation.

increase at day 7 and a decrease thereafter (Fig. 1a). The concentrations of $\mathrm{NH}_{4}^{+}$decreased in the unamended soil with EC 30, 80, and $146 \mathrm{dS} \mathrm{m}^{-1}$ and amended soil sludge spiked with PAHs at the onset of the experiment and tended to increase toward the end (Fig. 1b). The concentrations of $\mathrm{NH}_{4}^{+}$soil with EC $6 \mathrm{dS} \mathrm{m}{ }^{-1}$ amended or not with wastewater sludge and spiked with PAHs showed more fluctuations over time (Figs 1b-c). Mean concentrations of $\mathrm{NH}_{4}^{+}$were larger in the control with EC $6 \mathrm{dS} \mathrm{m}^{-1}$ than in soil with EC $30 \mathrm{dS} \mathrm{m}^{-1}$ (Table 2). Contaminating the soil with PAHs increased the concentrations of $\mathrm{NH}_{4}^{+}$compared to the uncontaminated soil, except in soil with EC $146 \mathrm{dS} \mathrm{m}^{-1}$ (Fig. 1b). Application of sludge to the PAH-contaminated soil increased the amount of $\mathrm{NH}_{4}^{+}$in soil, except in soil with EC $6 \mathrm{dS} \mathrm{m}^{-1}$.

The concentration of $\mathrm{NO}_{2}^{-}$in the control treatment and soil spiked with PAHs showed little fluctuation over time except in the uncontaminated soil with EC $6 \mathrm{dS} \mathrm{m}^{-1}$, where it increased until day 28 and decreased again (Figs 2a-b). The concentration of $\mathrm{NO}_{2}{ }^{-}$in the soil spiked with PAHs and amended with PAHs showed more fluctuations over time compared to the other treatments. Spiking soil with PAHs increased the concentration of $\mathrm{NO}_{2}{ }^{-}$except in soil with EC $80 \mathrm{dS} \mathrm{m}^{-1}$ (Table 2). Application of wastewater sludge to the PAH-contaminated soil increased the concentration of $\mathrm{NO}_{2}{ }^{-}$in all soils compared to the PAH-contaminated soil.

Concentrations of $\mathrm{NO}_{3}^{-}$showed no clear pattern over time in all treatments (Figs $3 \mathrm{a}-\mathrm{c}$ ). The mean concentration of $\mathrm{NO}_{3}{ }^{-}$was significantly greater in the soil with EC 80
$\mathrm{dS} \mathrm{m} \mathrm{m}^{-1}$ than in soil with EC $6 \mathrm{dS} \mathrm{m}^{-1}$ or $30 \mathrm{dS} \mathrm{m}^{-1}$, but significantly lower than in soil with EC $146 \mathrm{dS} \mathrm{m}^{-1}$ (Table 2 ). The application of sludge or contaminating soil with PAHs decreased the mean concentration of $\mathrm{NO}_{3}^{-}$, except in soil with EC $146 \mathrm{dS} \mathrm{m}^{-1}$.

The concentration of PHEN decreased sharply in soil with EC $6 \mathrm{dS} \mathrm{m}^{-1}$ in the first 14 days, but did not change significantly thereafter (Fig. 4a). Applying sludge to soil with $6 \mathrm{dS} \mathrm{m} \mathrm{m}^{-1}$ accelerated the removal of PHEN from soil and decreased the concentration after 56 days $(p<0.05)$ (Fig. 4b). The concentration of PHEN decreased

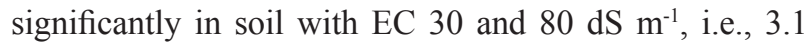
$\mathrm{mg} \mathrm{kg}^{-1}$ day $^{-1}$ (standard error of the estimate (SEE) 0.7) and $-4.6 \mathrm{mg} \mathrm{kg}^{-1}$ day $^{-1}$ (SEE 1.4), respectively. Application of sewage sludge decreased the concentration PHEN and ANTHR in soil with EC 30 and $80 \mathrm{dS} \mathrm{m}^{-1}$ after 56 days. The concentration of PHEN decreased sharply in soil with EC $146 \mathrm{dS} \mathrm{m}^{-1}$ in the first 14 days, but did not change significantly thereafter. Applying sludge to soil with 146 $\mathrm{dS} \mathrm{m}^{-1}$ had no significant effect on the concentration of PHEN after 56 days. The mean concentration of PHEN was significantly lower in soil with EC $6 \mathrm{dS} \mathrm{m}^{-1}$ than in soil with EC 30 and $80 \mathrm{dS} \mathrm{m}^{-1}$, but higher than in soil with EC $146 \mathrm{dS} \mathrm{m} \mathrm{m}^{-1}$ - independent of the application of wastewater sludge $(p<0.05)$.

The concentration of ANTHR decreased in soil with EC $6 \mathrm{dS} \mathrm{m}^{-1}$ between days 7 and 14, but did not change significantly thereafter (Fig. 5a). Applying sludge to soil with $6 \mathrm{dS} \mathrm{m}^{-1}$ accelerated the removal and decreased the amount of ANTHR after 56 days (Fig. 5b). The concentration of ANTHR in soil with EC 30 and $80 \mathrm{dS} \mathrm{m}^{-1}$ was lower after 56 days than at the onset of the incubation, although decreases were small, i.e., only 5\% ANTHR was removed in soil with EC $30 \mathrm{dS} \mathrm{m}^{-1}$ and $12 \%$ in soil with $80 \mathrm{dS} \mathrm{m}^{-1}$ after 56 days. Applying sludge to these two soils decreased the amount of ANTHR significantly compared to the unamended soil after 56 days $(p<0.05)$. The concentration of ANTHR decreased sharply in soil with EC $146 \mathrm{dS} \mathrm{m}^{-1}$ between days 7 and 14, but did not change significantly thereafter (Fig. 1a). Applying sludge to the PAHs contaminated soil with $146 \mathrm{dS} \mathrm{m}^{-1}$ had no significant effect on the concentration of ANTHR. The mean concentration of ANTHR was significantly lower in soil with EC $6 \mathrm{dS} \mathrm{m}^{-1}$ than in soil with EC 30 and $80 \mathrm{dS}$ $\mathrm{m}^{-1}$, but significantly higher than in soil with EC $146 \mathrm{dS}$ $\mathrm{m}^{-1}(p<0.05)$. In the sludge-amended soil the concentration of ANTHR was significantly higher in soil with EC 30 and $80 \mathrm{dS} \mathrm{m}^{-1}$ than in soil with EC 6 and $146 \mathrm{dS} \mathrm{m}^{-1}(p<0.05)$.

\section{Discussion}

Contaminating soil with PAHs increased $\mathrm{CO}_{2}$ emissions. It can be speculated that the acetone used to contaminate the soil that was not removed served as C-substrate, thereby increasing emissions of $\mathrm{CO}_{2}$. Microorganisms have been isolated from soil capable of degrading acetone under aerobic conditions [13]. The contribution of PAHs in the emission of $\mathrm{CO}_{2}$ was presumably low as 
Table 2. Concentrations of $\mathrm{NH}_{4}^{+}, \mathrm{NO}_{2}^{-}$, and $\mathrm{NO}_{3}^{-}\left(\mathrm{mg} \mathrm{N} \mathrm{kg}^{-1}\right.$ soil), and $\mathrm{CO}_{2}$ emission rates $\left(\mathrm{mg} \mathrm{C} \mathrm{kg}^{-1}\right.$ soil day $\left.{ }^{-1}\right)$ in soil with different electrolytic conductivities (EC) contaminated with or without anthracene and phenanthrene and amended with or without wastewater sludge incubated aerobically at $25 \pm 2^{\circ} \mathrm{C}$ for 56 days.

\begin{tabular}{|c|c|c|c|c|c|}
\hline \multirow{2}{*}{ 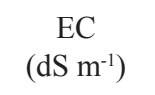 } & \multicolumn{5}{|c|}{$\mathrm{CO}_{2}$ emission rate $\left(\mathrm{mg} \mathrm{C} \mathrm{kg}^{-1} \mathrm{day}^{-1}\right)$} \\
\hline & Soil control & Soil + PAHs & Soil + PAHs + sludge & $\mathrm{SEE}^{\mathrm{a}}$ & P-value \\
\hline 6 & $17.1 \mathrm{c}^{\mathrm{b}} \mathrm{A}^{\mathrm{c}}$ & $80.6 \mathrm{~b} \mathrm{~A}$ & 107.7 a A & 3.7 & $p<0.0001$ \\
\hline 30 & $8.6 \mathrm{c} \mathrm{C}$ & $17.3 \mathrm{~b} \mathrm{~B}$ & 74.4 a B & 2.6 & $p<0.0001$ \\
\hline 80 & 12.9 c B & $16.0 \mathrm{~b} \mathrm{~B}$ & 20.9 a C & 1.3 & $p<0.0001$ \\
\hline 146 & 13.7 a B & 14.0 a B & 14.9 a D & 2.4 & $p<0.0001$ \\
\hline SEE & 2.0 & 2.4 & 3.2 & & \\
\hline P-value & $p<0.0001$ & $p<0.0001$ & $p<0.0001$ & & \\
\hline \multicolumn{6}{|c|}{ Concentration of $\mathrm{NH}_{4}^{+}\left(\mathrm{mg} \mathrm{N} \mathrm{kg}^{-1}\right)$} \\
\hline 6 & $7.9 \mathrm{~b} \mathrm{~A}$ & $15.1 \mathrm{a} \mathrm{A}$ & $9.4 \mathrm{~b} \mathrm{~B}$ & 4.4 & $p=0.0003$ \\
\hline 30 & $4.8 \mathrm{~b} \mathrm{~B}$ & $5.4 \mathrm{~b} \mathrm{C}$ & 8.6 a B & 1.5 & $p<0.0001$ \\
\hline 80 & $6.0 \mathrm{c} \mathrm{AB}$ & $9.7 \mathrm{~b} \mathrm{~B}$ & $13.1 \mathrm{a} \mathrm{A}$ & 1.6 & $p<0.0001$ \\
\hline 146 & $6.6 \mathrm{a} \mathrm{AB}$ & 5.7 a C & 7.9 a B & 2.3 & $p=0.0047$ \\
\hline MSD & 1.9 & 3.4 & 3.3 & & \\
\hline P-value & $p=0.0009$ & $p<0.0001$ & $p<0.0002$ & & \\
\hline \multicolumn{4}{|c|}{ Concentration of $\mathrm{NO}_{2}^{-}\left(\mathrm{mg} \mathrm{N} \mathrm{kg}^{-1}\right)$} & MSD & \\
\hline 6 & $1.0 \mathrm{~b} \mathrm{C}$ & $1.5 \mathrm{a} \mathrm{D}$ & 1.6 a D & 0.4 & $p=0.0024$ \\
\hline 30 & $1.4 \mathrm{~b} \mathrm{C}$ & $2.2 \mathrm{~b} \mathrm{C}$ & 5.3 a C & 1.2 & $p<0.0001$ \\
\hline 80 & $7.8 \mathrm{~b} \mathrm{~A}$ & $5.9 \mathrm{c} \mathrm{A}$ & 10.0 a B & 1.4 & $p<0.0001$ \\
\hline 146 & $4.0 \mathrm{~b} \mathrm{~B}$ & $4.1 \mathrm{~b} \mathrm{~B}$ & $12.4 \mathrm{a} \mathrm{A}$ & 1.2 & $p<0.0001$ \\
\hline MSD & 0.8 & 0.5 & 1.9 & & \\
\hline P-value & $p<0.0001$ & $p<0.0001$ & $p<0.0001$ & & \\
\hline $\mathrm{EC} / \mathrm{dS} \mathrm{m}^{-1}$ & \multicolumn{3}{|c|}{ Concentration of $\mathrm{NO}_{3}^{-}\left(\mathrm{mg} \mathrm{N} \mathrm{kg}^{-1}\right)$} & MSD & P-value \\
\hline 6 & 22 a C & $11 \mathrm{~b} \mathrm{C}$ & $10 \mathrm{~b} \mathrm{C}$ & 6 & $p<0.0001$ \\
\hline 30 & 20 a C & $14 \mathrm{~b} \mathrm{BC}$ & $15 \mathrm{~b} \mathrm{C}$ & 3 & $p<0.0001$ \\
\hline 80 & 34 a B & $24 \mathrm{~b} \mathrm{~B}$ & $27 \mathrm{~b} \mathrm{~B}$ & 5 & $p<0.0001$ \\
\hline 146 & 86 a A & 86 a A & 90 a A & 15 & $p=0.7320$ \\
\hline MSD & 10 & 11 & 9 & & \\
\hline P-value & $p<0.0001$ & $p<0.0001$ & $p<0.0001$ & & \\
\hline
\end{tabular}

aSEE: standard error of the estimate

${ }^{\mathrm{b}}$ values with the same letter are not significantly affected by treatment

${ }^{c}$ values with the same capital letter are not significantly different between the soil

${ }^{\mathrm{d}} \mathrm{MSD}$ : minimal significant difference

mineralization of PAHs in soil is low or non-existent [14]. In previous experiments, we found that acetone, used as a carrier to spike soil with PAHs, inhibited microbial activity in Texcoco soil with EC $56 \mathrm{dS} \mathrm{m}^{-1}$ after 7 days [15]. We speculated that if acetone inhibited microbial activity it would only be temporary [16]. Acetone might kill soil microorganisms so that microbial activity and emissions of $\mathrm{CO}_{2}$ decrease, but the killed microorganisms will also serve as a $\mathrm{C}$-substrate for the surviving microorganisms, thereby increasing $\mathrm{CO}_{2}$ emissions [15]. This was found in this study in soil with EC $146 \mathrm{dS} \mathrm{m}^{-1}$. The emission of $\mathrm{CO}_{2}$ was lower in contaminated PAHs than in the uncontaminated until day 14 , but was larger afterward.

The difference in $\mathrm{CO}_{2}$ emissions between the soil spiked with PAHs and the uncontaminated soil decreased with increased salinity. In previous experiments, it was found that mineralization of ${ }^{14} \mathrm{C}$-labelled glucose and maize also decreased with increased salinity [17]. 


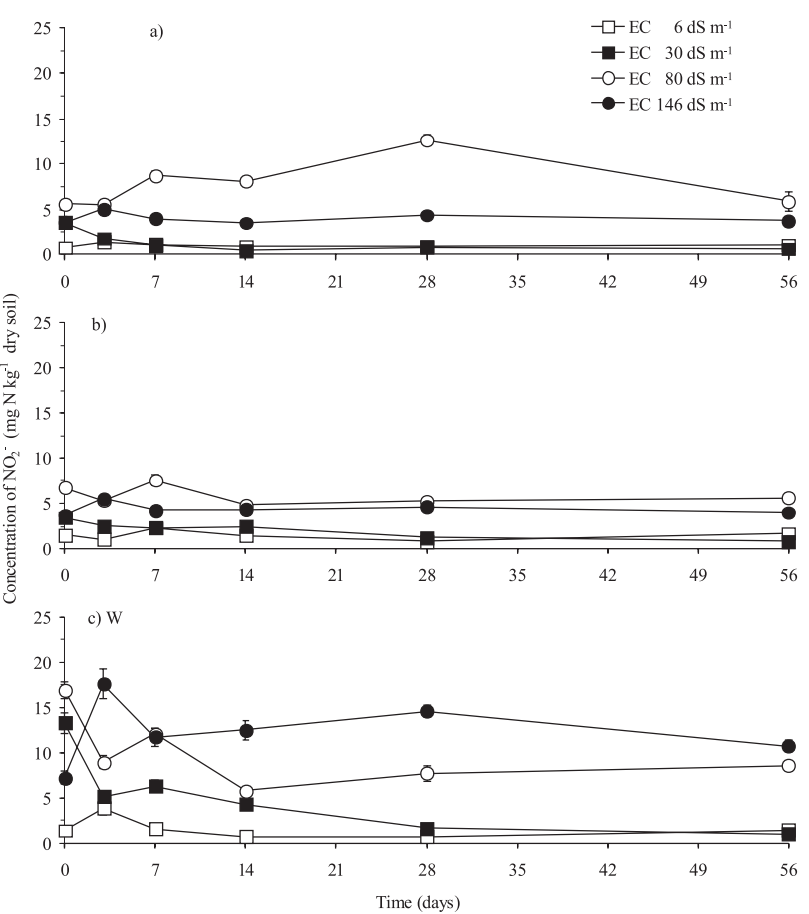

Fig. 2. Concentration of nitrite $\left(\mathrm{mg} \mathrm{N} \mathrm{kg}^{-1}\right)$ in a) soil, b) soil spiked with anthracene and phenanthrene, or c) soil spiked with anthracene and phenanthrene and amended with wastewater sludge with electrolytic conductivity (EC) $6 \mathrm{dS} \mathrm{m}^{-1}(\square), 30 \mathrm{dS}$ $\mathrm{m}^{-1}(\boldsymbol{\square}), 80 \mathrm{dS} \mathrm{m}^{-1}(\mathrm{O})$, or $146 \mathrm{dS} \mathrm{m}^{-1}(\bullet)$ incubated aerobically at $22 \pm 2^{\circ} \mathrm{C}$ for 56 days. Bars are \pm one standard deviation.

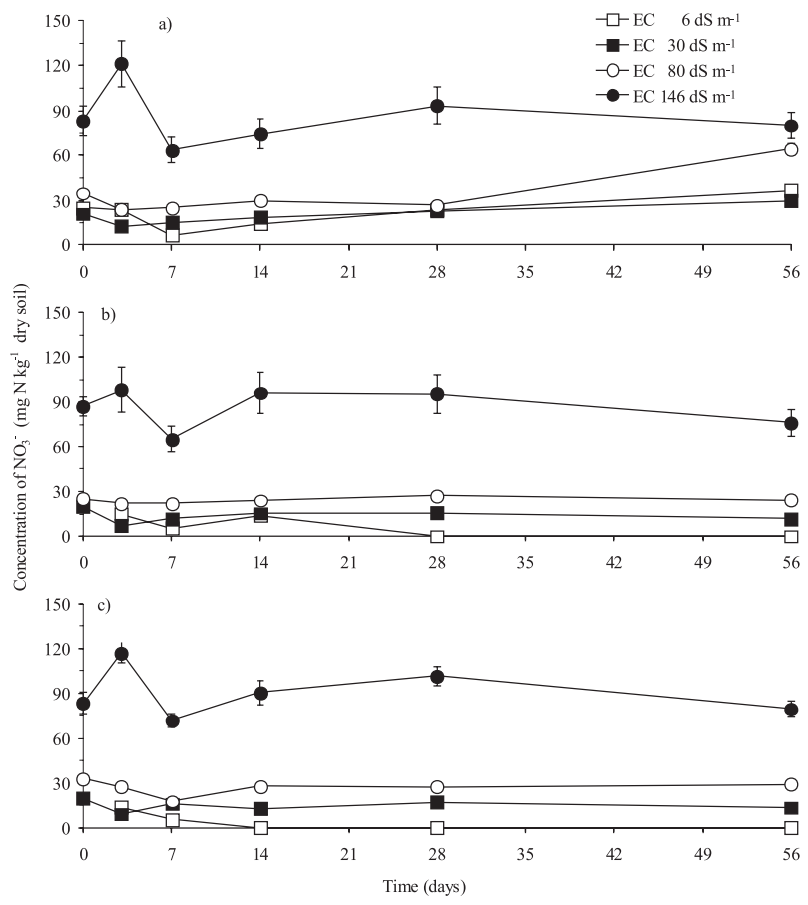

Fig. 3. Concentration of nitrate $\left(\mathrm{mg} \mathrm{N} \mathrm{kg}^{-1}\right)$ in a) soil, b) soil spiked with anthracene and phenanthrene, or c) soil spiked with anthracene and phenanthrene and amended with wastewater sludge with electrolytic conductivity (EC) $6 \mathrm{dS} \mathrm{m}^{-1}(\square), 30 \mathrm{dS}$ $\mathrm{m}^{-1}(\mathbf{\square}), 80 \mathrm{dS} \mathrm{m}^{-1}(\mathrm{O})$, or $146 \mathrm{dS} \mathrm{m}^{-1}(\bullet)$ incubated aerobically at $22 \pm 2^{\circ} \mathrm{C}$ for 56 days. Bars are \pm one standard deviation.
It has to be remembered, however, that other soil characteristics changed in the studied soils that are known to affect the decomposition of added organic material. Soil characteristics such as $\mathrm{pH}$ [18], CEC, soil structure [19], sodicity [20], clay content [21], specific surface area of the clay, and the nature of the clay mineral [22] affect mineralization of organic material.

It is well known that the application of wastewater sludge increases $\mathrm{CO}_{2}$ emissions from soil. Wastewater sludge contains large amounts of easily decomposable organic material that is rapidly mineralized when added to soil [9, 23]. For instance, Zhang et al. [24] reported that approximately $40 \%$ of the organic material in sludge mineralized within the first 50 days. The difference in $\mathrm{CO}_{2}$ emissions between the PAH-contaminated soil amended with sludge and the soil treatment decreased with increased salinity. This appears to indicate again that increased salinity decreased mineralization of added organic material.

Spiking soil with PAHs had no clear effect on the concentration of $\mathrm{NO}_{2}^{-}$, but the addition of wastewater sludge increased it significantly with the largest increase found in the soil with the highest EC. The $\mathrm{NH}_{4}^{+}$or the mineralized organic material of the wastewater sludge is oxidized to $\mathrm{NO}_{2}^{-}$and $\mathrm{NO}_{3}^{-}$in soil. It is well known that nitrifiers are affected by elevated salt content and the oxidation of $\mathrm{NO}_{2}^{-}$is more sensitive to increased soil salt content than the oxidation of $\mathrm{NH}_{4}^{+}$[25]. As such, the concentration of $\mathrm{NO}_{2}^{-}$increased with the largest increase found in soil with the largest EC. However, oxidation of

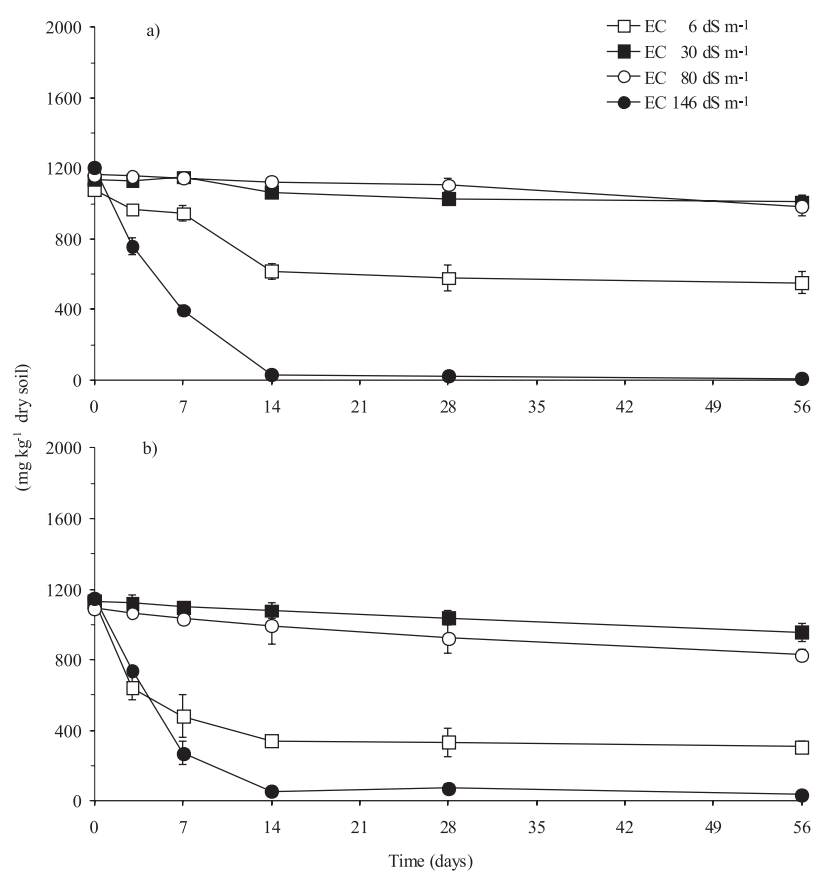

Fig. 4. Concentration of phenanthrene $\left(\mathrm{mg} \mathrm{kg}^{-1}\right)$ in a) unamended soil or b) soil amended with wastewater sludge with electrolytic conductivity (EC) $6 \mathrm{dS} \mathrm{m}^{-1}(\square), 30 \mathrm{dS} \mathrm{m}^{-1}(\boldsymbol{\square}), 80 \mathrm{dS} \mathrm{m}^{-1}(O)$, or $146 \mathrm{dS} \mathrm{m}^{-1}(\bullet)$ incubated aerobically at $22 \pm 2^{\circ} \mathrm{C}$ for 56 days. Bars are \pm one standard deviation. 


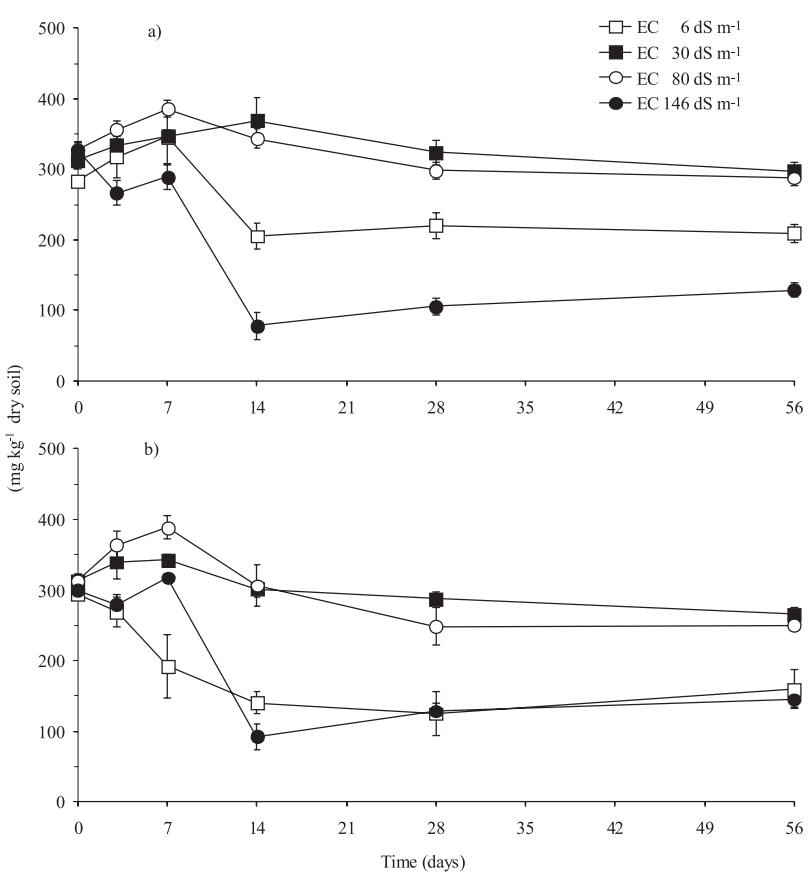

Fig. 5. Concentration of anthracene $\left(\mathrm{mg} \mathrm{kg}^{-1}\right)$ in a) unamended soil or b) soil amended with wastewater sludge with electrolytic conductivity (EC) $6 \mathrm{dS} \mathrm{m}^{-1}(\square), 30 \mathrm{dS} \mathrm{m}^{-1}(\boldsymbol{\square}), 80 \mathrm{dS} \mathrm{m}^{-1}(\mathrm{O})$, or $146 \mathrm{dS} \mathrm{m}^{-1}(\bullet)$ incubated aerobically at $22 \pm 2^{\circ} \mathrm{C}$ for 56 days. Bars are \pm one standard deviation.

$\mathrm{NO}_{2}^{-}$occurred even in soil with EC $146 \mathrm{dS} \mathrm{m}^{-1}$, as large amounts of $\mathrm{NO}_{3}^{-}$were detected.

Spiking soil with PAHs decreased the concentration of $\mathrm{NO}_{3}{ }^{-}$independent of the application of wastewater sludge, except in soil with EC $146 \mathrm{dS} \mathrm{m}^{-1}$. Both acetone, used to spike the soil with ANTHR, and PHEN and the PAHs added to soil do not contain $\mathrm{N}$, so their decomposition will induce the immobilization of mineral $\mathrm{N}$, except in soil with EC $146 \mathrm{dS} \mathrm{m}^{-1}$, where their mineralization was low. The immobilization of $\mathrm{NO}_{3}^{-}$, however, is normally inhibited by even small amounts of $\mathrm{NH}_{4}{ }^{+}$. Yang et al. [26] stated that assimilatory reduction of $\mathrm{NO}_{3}^{-}$is not expected to be important in soil unless there are $\mathrm{NH}_{4}^{+}$-free microsites in the soil. $\mathrm{NH}_{4}^{+}$was always present in the soils so it did not inhibit the immobilization of $\mathrm{NO}_{3}{ }^{-}$in Texcoco soil. In previous experiments, it was found that the addition of an easily decomposable $\mathrm{C}$-substrate to soil decreased the concentration of $\mathrm{NO}_{3}{ }^{-}$and increased the concentration of $\mathrm{NO}_{2}^{-}$independent of the concentration of $\mathrm{NH}_{4}^{+}$in soil [27]. We speculated that the aerobic respiration $\mathrm{NO}_{3}^{-}$by Archaea might explain part of the decrease in the concentration of $\mathrm{NO}_{3}^{-}$[28]. Additionally, the concentration of $\mathrm{NO}_{3}^{-}$might have decreased as a result of anaerobic reduction or denitrification, aerobic respiration, assimilatory reduction, or a combination of these processes. In addition, it has to be remembered that the soil of the former lake Texcoco is an extreme soil that is highly saline and alkaline and that has $\mathrm{Na}^{+}, \mathrm{Cl}^{-}, \mathrm{HCO}_{3}^{-}$, and $\mathrm{CO}_{3}{ }^{2-}$ as predominant ions. Valenzuela-Encinas et al. [29] showed that the archaeal diversity in an alkaline-saline soil was low with yet uncharacterized and unclassified species, but some of the clones identified were capable of reducing $\mathrm{NO}_{3}^{-}$ aerobically to $\mathrm{NO}_{2}^{-}$, such as Halorubrum alkaliphilum, Natronococcus amylolyticus, Natrinema pallidum, and Natrinema pellirubrum. Dendooven et al. [30] stated that the soil of the former Lake Texcoco can be categorized as a unique ecosystem. Actually, this environment affects the dynamics of $\mathrm{C}$ and $\mathrm{N}$ differently than in a typical soil. Additionally, microorganisms immobilize $\mathrm{NH}_{4}{ }^{+} \mathrm{N}$ in excess of what was required for metabolic activity. Moreover, large amounts of $\mathrm{NO}_{3}^{+}$are reduced under aerobic conditions to $\mathrm{NO}_{2}{ }^{-}$, and smaller amounts of $\mathrm{NH}_{4}^{+}$ when an easily decomposable $\mathrm{C}$-substrate is added to soil in excess of what is required for normal metabolic activity and it is not inhibited by $\mathrm{NH}_{4}^{+}$, L-glutamine, acetylene, or $\mathrm{O}_{2}$. According to Dendooven et al. [30], the metabolic mechanisms involved in some processes of the soil from Texcoco are still not fully understood and need to be unravelled.

The concentrations of PHEN and ANTHR decreased in soil with EC $6 \mathrm{dS} \mathrm{m}^{-1}$ until day 14 and remained constant thereafter. Approximately $49 \%$ of the PHEN and $26 \%$ of ANTHR added to soil was removed from within 56 days. It is well known that autochthonous microorganisms can remove PAHs from soil [31] - even in the presence of salt [32]. In a previous experiment, 99\% PHEN and $85 \%$ ANTHR were removed from an agricultural soil [23]. The removal of PHEN and ANTHR was much lower from soil with EC $30 \mathrm{dS} \mathrm{m}^{-1}$ (i.e., $11 \%$ and $5 \%$, respectively), or with EC $60 \mathrm{dS} \mathrm{m}^{-1}$ (i.e., $15 \%$ and $12 \%$, respectively). It was hypothesized that the high $\mathrm{pH}$ and $\mathrm{EC}$ in Texcoco soil inhibited the removal of PAHs [8]. However, nearly all the ANTHR and PHEN was removed from soil with EC 146 $\mathrm{dS} \mathrm{m}^{-1}$ after 56 days, i.e., $>95 \%$. This made it clear that other factors affected the removal of PAHs from soil, and salt content and $\mathrm{pH}$ were not determinant factors [33-34].

A PCA analysis of the soil factors indicated that none of the soil characteristics measured (i.e., EC, WHC, particle size distribution, and organic and inorganic $\mathrm{C}$ or $\mathrm{pH}$ ) determined the removal of PHEN or ANTHR from soil (Fig. 6). The four soils studied were clearly separated from each other, but there was no clear relationship between soil characteristics and the amount of PAHs removed from the soils. For instance, the soils with EC $80 \mathrm{dS} \mathrm{m}^{-1}$ had a positive $\mathrm{PC} 1$, i.e., high $\mathrm{WHC}$ and silt content, while the soil with EC $30 \mathrm{dS} \mathrm{m}^{-1}$ had a negative PC1, i.e., high sand and organic $\mathrm{C}$ content, but similar amounts of PAHs were removed. Additionally, the removal of PAHs was larger in soil with EC $146 \mathrm{dS} \mathrm{m}^{-1}$ than in soil with EC of $6 \mathrm{dS} \mathrm{m}^{-1}$, so that salt content was not the determinant factor. Even the microbial activity as evidenced by the emission of $\mathrm{CO}_{2}$ was not related to the removal of PAHs from soil.

The production of $\mathrm{CO}_{2}$ was similar in soil with EC $80 \mathrm{dS} \mathrm{m}^{-1}$ and $146 \mathrm{dS} \mathrm{m}^{-1}$, but the removal of PHEN and Antra was much larger in the latter than in the first. As such, the EC and the other measured soil characteristics did not determine removal of PAHs from soil and another unmeasured factor or factors intervened. These factors, such as specific surface area of the clays and/ or the nature of the clay mineral [21-22], might have 


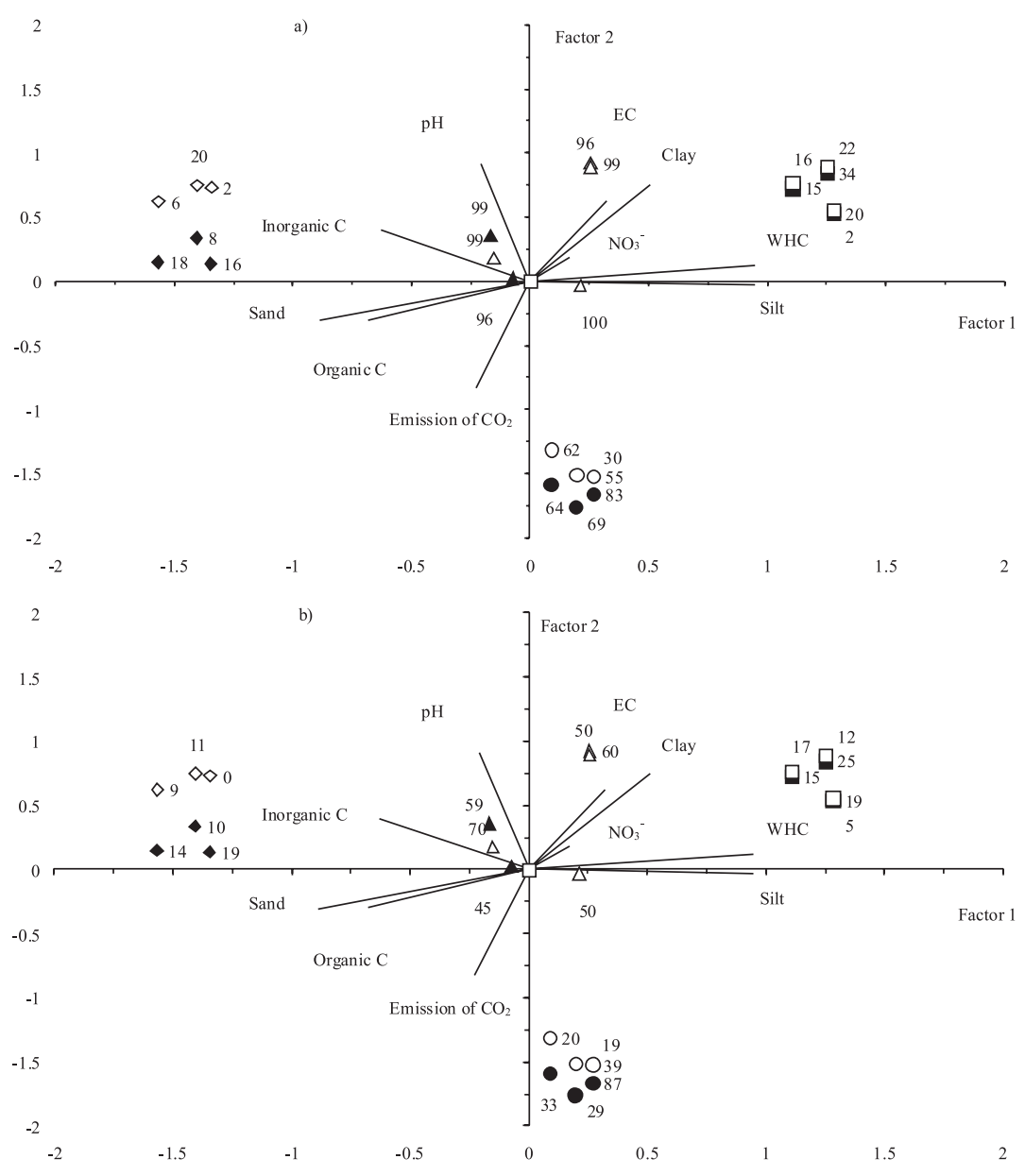

Fig. 6. Principal component analysis (PCA) performed on soil properties data after a varimax rotation with emission of $\mathrm{CO}_{2}$ and concentration of $\mathrm{NO}_{3}^{-}$after 56 days, organic $\mathrm{C}$, inorganic, WHC (water holding capacity), $\mathrm{pH}$, EC (electrolytic conductivity), clay, loam, and sand content. The first factor (PC1) loaded by sand, silt and clay content, WHC, and inorganic and organic $\mathrm{C}$ explained $58 \%$ of the variation, while the second factor ( $\mathrm{PC} 2)$ loaded by $\mathrm{pH}, \mathrm{EC}$, clay content, inorganic $\mathrm{C}$, and emission of $\mathrm{CO}_{2}$ explained $23 \%$ of the variation. Unamended soil $(n=3)$ with EC $6 \mathrm{dS} \mathrm{m}^{-1}(\bigcirc), 30 \mathrm{dS} \mathrm{m}^{-1}(\diamond), 80 \mathrm{dS} \mathrm{m}^{-1}(\square)$, or $146 \mathrm{dS} \mathrm{m}^{-1}(\triangle)$ soil or with EC $6 \mathrm{dS} \mathrm{m} \mathrm{m}^{-1}(\bullet)$, $30 \mathrm{dS} \mathrm{m}^{-1}(\bullet), 80 \mathrm{dS} \mathrm{m}^{-1}(\boldsymbol{\square})$, or $146 \mathrm{dS} \mathrm{m}^{-1}(\boldsymbol{\Delta})$ amended with wastewater sludge incubated aerobically at $22 \pm 2^{\circ} \mathrm{C}$ for 56 days. Values besides the symbols are the percentages (mean of $n=3$ ) of a) phenanthrene or b) anthracene removed from that soil after 56 days.

affected availability and thus the removal of PAHs from soil. It can be speculated that the 'availability' or 'bioaccessibility' of the studied PAHs might have been another factor that determined the removal of ANTHR and PHEN from soil [35]. In a previous experiment, it was found that the removal of ANTHR was faster from the top $0-2 \mathrm{~cm}$ layer than from the 2-8 or 8-15 cm layers [8]. Further investigation revealed that fluctuating water contents increased anthracene availability, contributing to increased removal [15]. It can be speculated that the large salt content in soil with EC $146 \mathrm{dS} \mathrm{m}^{-1}$ dispersed the soil particles in such a way that the PAHs were not physically protected and became available for degradation [36]. Consequently, the removal of PAHs was not inhibited by salts in soil with EC $146 \mathrm{dS} \mathrm{m}^{-1}$.

It is worth noticing that the percentages of ANTHR and PHEN removed from soil with EC 30 and $80 \mathrm{dS} \mathrm{m}^{-1}$ were similar after 56 days, but in soil with EC 6 and 146 $\mathrm{dS} \mathrm{m}^{-1}$ the dissipation of ANTHR was lower than that of PHEN. The removal of ANTHR is normally slower from soil than that of PHEN. This can be attributed to the low solubility of ANTHR in aqueous systems $\left(0.07 \mathrm{mg} \mathrm{L}^{-1}\right)$ compared to that of PHEN $\left(1.29 \mathrm{mg} \mathrm{L}^{-1}\right)$, which renders it only slowly available for microbial degradation [2]. This would indicate in soil with EC 30 and $80 \mathrm{dS} \mathrm{m}^{-1}$, the availability or 'bio-accessibility' of PHEN and ANTHR was low, so that their removal was low and similar.

It is well known that the application of organic material accelerates the removal of PAHs from soil [35, 37]. Adding sludge to soil can affect the removal of PAHs in different ways. First, the sludge contains larger amounts of $\mathrm{C}$-substrate that will stimulate microbial activity, thereby accelerating the removal of PAHs from soil. Second, the sludge contains nutrients that will further stimulate microbial activity. Third, sludge contains large amounts of microorganisms that can contribute to the removal of PAHs from soil. Fourth, sludge can change soil conditions, such as $\mathrm{pH}$ and EC, thereby stimulating or inhibiting the removal of PAHs. Fifth, organic matter might conduce absorption and/or adsorption processes on the dissipation of PAH concentrations. Wastewater sludge reduced the concentrations of PHEN and ANTHR 
in soil after 56 days compared to the amount extracted at the beginning of the experiment, although the effect was much smaller in soils with EC 30 and $80 \mathrm{dS} \mathrm{m}^{-1}$ than in soil with EC $6 \mathrm{dS} \mathrm{m}^{-1}$. In soil with EC $146 \mathrm{dS} \mathrm{m}^{-1}$ the removal rate of PHEN and ANTHR was so high that sludge had no effect on their dissipation rate. This would indicate that a positive effect of wastewater sludge on the removal of PHEN and ANTHR will only be observed when the PAHs are available and not shielded from microbial degradation.

\section{Conclusions}

It was concluded that $\mathrm{CO}_{2}$ emissions increased when soil was spiked with PAHs and further increased when amended with wastewater sludge, but the increase decreased with increased soil salt content. Spiking soil with ANTHR and PHEN decreased the concentration of $\mathrm{NO}_{3}^{-}$. The removal of PAHs was high in soil with 6 or 146 $\mathrm{dS} \mathrm{m}{ }^{-1}$, but low in soils with EC 30 or $80 \mathrm{dS} \mathrm{m}^{-1}$. It appears that 'bio-accessibility' of ANTHR and PHEN in soil was a more important determinant in their removal than soil characteristics such as EC, $\mathrm{pH}$, particle size distribution, organic matter content, or microbial activity. Wastewater sludge had a positive effect on the removal of PHEN and ANTHR from soil, but the degree of its effect appeared to be related to the availability of the contaminant.

\section{Acknowledgements}

Our research was funded by 'Consejo Nacional de Ciencia y Tecnología' (CONACyT, México) project No. 39801-Z, Cinvestav Saltillo and Cinvestav Zacatenco (Mexico). G. C.-L. received grant-aided support from 'Ayudantes de Investigador SNI nivel III, Sistema Nacional de Investigadores, CONACyT'.

\section{References}

1. SRINIENG K., SAISAVOEY T., KARNCHANATAT A. Effect of salinity stress on antioxidative enzyme activities in tomato cultured in vitro. Pak. J. Bot. 47(1), 1, 2015.

2. ADELAJA O., KESHAVARZ T., KYAZZE G. The effect of salinity, redox mediators and temperature on anaerobic biodegradation of petroleum hydrocarbons in microbial fuel cells. J. Hazard. Mater. 283, 211, 2015.

3. FERNANDEZ-LUQUEÑO F., VALENZUELA-ENCINAS C., MARSCH R., MARTINEZ-SUAREZ C., VAZQUEZNUNEZ E., DENDOOVEN L. Microbial communities to mitigate contamination of PAHs in soil-possibilities and challenges: a review. Environ. Sci. Pollut. R. 18 (1), 12, 2011.

4. USEPA. Environmental Protection Agency. Proposed guidelines for carcinogen risk assessment. Federal Register 61, 1996

5. USEPA. Air emissions from scrap tire combustion. Office of research and development, US Environmental Protection Agency. EPA 600-R-97-115. Available on line at http://www.
epa.gov/OST/cs/congress.html. (Accessed December 10, 2015). 1999.

6. LIU J.Y., ZHUO Z.X., SUN S.Y., NING X.N., ZHAO S.Y., XIE W.M., WANG Y.J., ZHENG L., HUANG R., LI B. Concentrations of heavy metals in six municipal sludges from Guangzhou and their potential ecological risk assessment for agricultural land use. Pol. J. Environ. Stud. 24 (1), 165, 2015.

7. SAYARA T., CVANCAROVA M., CAJTHAML T., SARRA M., SANCHEZ A. Anaerobic bioremediation of PAH-contaminated soil: assessment of the degradation of contaminants and biogas production under thermophilic and mesophilic conditions. Environ. Eng. Manag. J. 14 (1), 153, 2015.

8. BETANCUR-GALVIS L.A., ALVAREZ-BERNAL D., RAMOS-VALDIVIA A.C., DENDOOVEN L. Bioremediation of polycyclic aromatic hydrocarboncontaminated saline-alkaline soils of the former Lake Texcoco. Chemosphere, 62 (11), 1749, 2006.

9. FERNANDEZ-LUQUEÑO F., MARSCH R., ESPINOSAVICTORIA D., THALASSO F., HIDALGO-LARA M.E., MUNIVE A., LUNA-GUIDO M.L., DENDOOVEN L. Remediation of PAHs in a saline-alkaline soil amended with wastewater sludge and the effect on dynamics of $\mathrm{C}$ and $\mathrm{N}$. Sci. Total Environ. 402 (1), 18, 2008.

10. FERNÁNDEZ-LUQUEÑO F., LÓPEZ-VALDEZ F., DENDOOVEN L., LUNA-SUAREZ S., CEBALLOSRAMIREZ J.M. Why wastewater sludge stimulates and accelerates removal of PAHs in polluted soils? Appl. Soil Ecol. 101, 1, 2016.

11. SONG Y.F., OU Z.Q., SUN T.H., YEDILER A., LORINCI G., KETTRUP A. Analytical method for polycyclic aromatic hydrocarbons (PAHs) in soil and plants samples. Chin. J. App. Ecol. 6 (1), 92, 1995.

12. SAS Institute. Statistic Guide for Personal Computers. Version 6.04, Edn. SAS Institute, Cary. 1989.

13. DIXON J.L., BEALE R., SARGEANT S.L., TARRAN G.A., NIGHTINGALE P.D. Microbial acetone oxidation in coastal seawater. Front. Microbiol. 5, 243, 2014.

14. ALONSO M.J.F., ONATE C.O., FERNANDEZ L.G., SANCHEZA.T. Soil $\mathrm{CO}_{2}$ efflux as early response assessment for remediation of diesel polluted soil. Span. J. Soil Sci. 6 (1), 51, 2016.

15. VAZQUEZ-NUÑEZ E., RODRIGUEZ V., GARCIAGAYTÁN A., LUNA-GUIDO M., BETANCUR-GALVIS L.A., MARSCH R, DENDOOVEN L. Using acetone as solvent to study removal of anthracene in soil inhibits microbial activity and alters nitrogen dynamics. Arch. Environ. Con. Tox. 57 (2), 239, 2009.

16. RAHIMNEJAD M., GHASEMI M., NAJAFPOUR G., GHOREYSHI A., BAKERI G., NEJAD S.H.H., TALEBNIA F. Acetone removal and bioelectricity generation in dual chamber microbial fuel cell. Am. J. Biochem. Biotech. 8 (4), 304, 2012.

17. LUNA-GUIDO M.L., VEGA J., PONCE-MENDOZA A., HERNÁNDEZ-HERNÁNDEZ H., MONTES M.C., DENDOOVEN L. Mineralization of ${ }^{14} \mathrm{C}$-labelled maize in alkaline saline soils. Plant Soil, 250 (1), 29, 2003.

18. CARLSON J., SAXENA J., BASTA N., HUNDAL L., BUSAKACCHI D., DICK R.P. Application of organic amendments to restore degraded soil: effects on soil microbial properties. Environ. Monit. Assess. 187 (3), 109, 2015.

19. YU Y., LIU J., LIU C.M., ZONG S., LU Z.H. Effect of organic materials on the chemical properties of saline soil in the Yellow river delta of China. Front Earth Sci-PRC, 9 (2), 259, 2015. 
20. ASSOULINE S., NARKIS K., GHERABLI R., SPOSITO G. Combined effect of sodicity and organic matter on soil properties under long-term irrigation with treated wastewater. Vadose Zone J. 15 (4), 1, 2016.

21. ELERT K., PARDO E.S., RODRIGUEZ-NAVARRO C. Influence of organic matter on the reactivity of clay minerals in highly alkaline environments. Appl. Clay Sci. 111, 27, 2015.

22. DURCE D., BRUGGEMAN C., MAES N., VAN RAVESTYN L., BRABANTS G. Partitioning of organic matter in boom clay: leachable vs mobile organic matter. Appl. Geochem. 63, 169, 2015.

23. FERNÁNDEZ-LUQUEÑO F., THALASSO F., LUNAGUIDO M.L. CEBALLOS-RAMÍREZ J.M., ORDOÑEZRUIZ I.M., DENDOOVEN L. Flocculant in wastewayter affects dynamics of inorganic $\mathrm{N}$ and accelerates removal of phenanthrene and anthracene in soil. J. Environ. Manage. 90 (8), 2813, 2009.

24. ZHANG Y., ZHU Y.G., HOUOT S., QIAO M., NUNAN N., GARNIER P. Remediation of polycyclic aromatic hydrocarbon (PAH) contaminated soil through composting with fresh organic wastes. Environ Sci. Pollut. R. 18 (9), 1574, 2011.

25. SONG H., CHE Z., CAO W.C., HUANG T., WANG J.G., DONG Z.R. Changing roles of ammonia-oxidizing bacteria and archea in a continuously acidifying soil caused by overfertilization with nitrogen. Environ Sci. Pollut. R. 23 (12), 11964, 2016.

26. YANG H.C., SHENG R., ZHANG Z.X., WANG L., WANG Q., WEI W.X. Responses of nitrifying and denitrifying bacteria to flooding-drying cycles in flooded rice soil. Appl. Soil Ecol. 103, 101, 2016.

27. THUILlE A., LAUFER J., HOHL C., GLEIXNER G. Carbon quality affects the nitrogen partitioning between plants and soil microorganisms. Soil Biol. Biochem. 81, 266, 2015.

28. JESUS H.E., PEIXOTO R.S., CURY J.C., VAN ELSAS J.D., ROSADO A.S. Evaluation of soil bioremediation techniques in an aged diesel spill at the Antarctic. Appl. Microbiol. Biot. 99 (24), 10815, 2015.
29. VALENZUELA-ENCINAS C., NERIA-GONZÁLEZ I., ALCANTARA-HERNÁNDEZ R.J., ENRIQUE-ARAGON J.A., ESTRADA-ALVARADO I., HERNANDEZRODRÍGUEZ C., DENDOOVEN L., MARSCH R. Phylogenetic analysis of the archaeal community in an alkaline-saline soil of the former lake Texcoco (Mexico). Extremophiles. 12 (2), 247, 2008.

30. DENDOOVEN L., ALCANTARA-HERNÁNDEZ R.J., VALENZUELA-ENCINAS C., LUNA-GUIDO M., PEREZ-GUEVARA F., MARSCH R. Dynamics of carbon and nitrogen in an extreme alkaline saline soil: A review. Soil Biol. \& Biochem. 42 (6), 865, 2010.

31. MANSUR A.A., ADETUTU E.M., KADALI K.K., MORRISON P.D., NURULITA Y., BALL A.S. Assessing the hydrocarbon degrading potential of indigenous bacteria isolated from crude oil tank bottom sludge and hydrocarboncontaminated soil of Azzawila oil refinery, Libya. Environ. Sci. Pollut. R. 21 (18), 10725, 2014.

32. WEN J.W., GAO D.W., ZHANG B., LIANG H. Cometabolic degradation of pyrene by indigenous white-rot fungus Pseudotrametes gibbosa from the northeast China. Int. Biodeter. Biodegr. 65 (4), 600, 2011.

33. LI X.J., WANG X., ZHANG Y.Y., CHENG L.J., LIU J., LI F., GAO B.L. ZHOU Q.X. Extended petroleum hydrocarbon bioremediation in saline soil using Pt.free multianodes microbial fuel cells. RSC Adv. 4 (104), 59803, 2014.

34. QIN X., TANG J.C., LI D.S., ZHANG Q.M. Effect of salinity on the bioremediation of petroleum hydrocarbons in a salinealkaline soil. Lett. Appl. Microbiol. 55 (3), 210, 2012.

35. FERNANDEZ-LUQUEÑO F., MENDOZA-CRISTINO R., DENDOOVEN L. Do application rates of wastewater sludge affect the removal of PAHs from an alkaline saline soil?. Pol. J. Environ. Stud. 25 (6), 2367, 2016.

36. CAI B., MA J., YAN G.X., DAI X.L., LI M., GUO S.H. Comparison of phytoremediation, bioaugmentation and natural attenuation for remediating saline soil contaminated by heavy crude oil. Biochem. Eng. J. 112, 170, 2016.

37. TIAN W.J., WANG L.J., LI D., LI F.S. Leachability of phenanthrene from soil under acid rain and its relationship with dissolved organic matter. Environ. Earth Sci. 73 (7), 3675, 2015. 